\title{
THE POSSIBILITY OF IMPLEMENTING CARBON LEVIES IN INDONESIA USING EXISTING LAW
}

\author{
Muhammad Sutartib ${ }^{1}$ \\ Muh Nurkhamid ${ }^{2}$ \\ ${ }^{1}$ Policy Analyst, Directorate General of Customs and Excise, Indonesia \\ ${ }^{2}$ Polytechnic of State Finance STAN, Indonesia \\ Email: muh.sutartib@kemenkeu.go.id \\ Email: muh.nurkhamid@pknstan.ac.id
}

\author{
ARTICLE INFORMATION \\ Received date \\ [16-09-2020]
}

Revision

[30-11-2020]

Accepted date

[22-12-2020]

\begin{abstract}
:
This qualitative research method aims to prove that without making new laws, Indonesia can still fulfill what is mandated in the Paris Agreement. Indonesia has ratified this agreement since 2016, so it must immediately take appropriate and concrete steps for reducing carbon dioxide emissions. A carbon tax is one of the most powerful tools to mitigate climate change, so many experts have suggested that Indonesia has to immediately implements a carbon tax as well. We suggest replacing the term of a carbon tax with carbon levy, to make it more flexible in its collection without having to enact new laws. A carbon tax is a corrective tax on goods that have a negative impact on their use, so there is a similarity between the philosophy of the carbon tax and the philosophy of excise. The weakness of the existing Excise Law is that it is only intended for tangible goods so that this Law cannot adopt carbon levies on activities that create a carbon footprint. This paper concludes that carbon levies in the form of excise taxes can be used to tax fossil fuels, while for activities that emit carbon dioxide, the levy uses the non-tax state levy mechanism.
\end{abstract}

Keywords: Paris Agreement, carbon tax, carbon levy, excise, non-tax state levy 


\section{INTRODUCTION}

According to data from Iqair (2020), Indonesia ranks 6 out of 98 countries as the country with the worst air quality. Indonesia's position is only above five other countries, i.e. Bangladesh, Pakistan, Mongolia, Afghanistan, and India. Jakarta is currently one of the cities with the worst air pollution and this is not surprising considering that Indonesia contributes $1.4 \%$ of global carbon emissions and ranks twelfth in 2017.

Based on I Dewa Made Raditya Margenta's (2020) writing entitled Carbon Tax Implementation in Indonesia, even though national carbon emissions have decreased since 2015, Indonesia should still strive to reduce carbon emissions, especially emissions from the energy sector. Carbon emissions from the energy sector caused by intensive fuel combustion have tended to increase since 2000. If we look at the report from the Ministry of Environment and Forestry of The Republic Indonesia (2019) compiled by I Dewa Made Raditya Margenta as can be seen in Figure 1, the industry and transportation sectors are the main contributors in fuel combustion. This indicates that to encourage national development, our country is very dependent on fossil energy.

Figure 1. Fuel combustion contributors by its sector in Indonesia

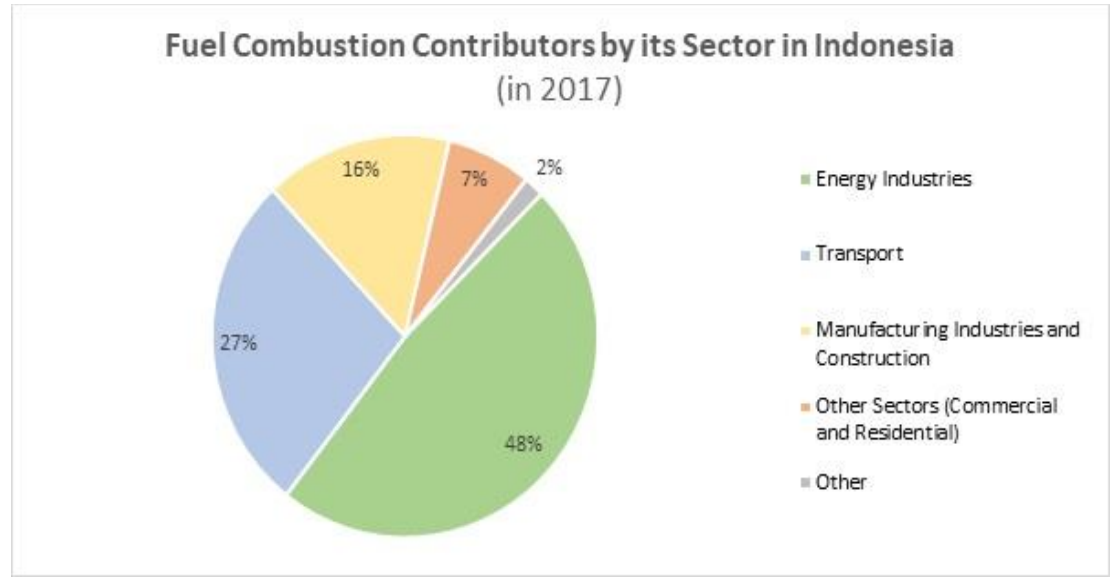

Source: Ministry of Environment and Forestry (2019)

How to measure performance in climate control efforts? The experts agreed to use carbon economic values as a universal measure reflected by Nationally Determined Contribution (NDC). The economic value of carbon or carbon pricing is the value of each unit of greenhouse gas emissions resulting from human activities and economic activities. Some discussions among internal government and related stakeholders, several ideas 
emerged that to carry out the implementation of the economic value of carbon can be achieved through several mechanisms, namely carbon trading, performance-based payments, carbon tax, and other mechanisms in line with the development of science and technology.

With the signing of Law Number 16 of 2016 Regarding Ratification of the Paris Agreement to the United Nations Framework Convention on Climate Change on October 24, 2016, means the Government of Indonesia has become one of the contracting parties of this Convention so that our country must immediately take appropriate steps to meet convention requirements. The Paris Agreement is an international agreement on climate change which contains the government's obligation in contributing to the reduction of Greenhouse Gas (GHG) emissions to limit the increase in global average temperatures below $2^{\circ} \mathrm{C}$ to $1.5^{\circ} \mathrm{C}$ from pre-industrialized temperature levels.

Carbon taxes are a powerful tool for reducing carbon dioxide emissions and this is supported by the IMF according to Emma Newburger's writing entitled A carbon tax is a 'single most powerful' way to climate change, IMF says published by CNBC 10 October 2019.

Carbon taxes have been imposed in several countries on fossil fuels such as petroleum, coal, and natural gas, but before this carbon tax became the subject of general discussion, commodities such as fossil fuels were taxed in the form of excise, environmental tax or energy tax in many countries. Whether the carbon tax will replace excise duties or will be used as an additional levy on fossil fuels (the excise is still levied) depends on the policies of each country.

The reasons for the imposition of a carbon tax or excise on fossil fuels are usually not very different. Such goods need to be levied because their consumption can cause negative externalities (carbon and excise taxes are negative externality taxes) so it is quite appropriate if carbon levies in Indonesia use an excise mechanism because according to the Excise Law of The Republic Indonesia No. 11 of 1995 as amended by Law No.39 of 1997, one of the reasons for the imposition of excise on goods is if the use of these goods can have a negative impact on society or the environment. The imposition of excise on fuel oil in several countries usually uses a specific system (i.g, the unit of the country's currency for each liter) with various assumptions (i.g, the more environmentally friendly 
the fuel is, the lower the excise rate), whereas the imposition of carbon taxes tends to be based on the amount of carbon dioxide produced by the use of the fuel. The more carbon dioxide produced per liter or kilogram of fuel, the higher tariff will be, although later the rate can be converted per liter / kilogram of fuel.

The imposition of carbon levies on fossil fuels such as coal, petroleum and natural gas as well as for activities that leave a carbon footprint will provide many benefits, including: (1) it can limit the use of fossil fuels that cause greenhouse gas emissions, (2) can accelerate the transformation to the use of environmentally friendly renewable energy, (3) the revenue from carbon levies can be used to finance climate change mitigation.

A study on the imposition of excise on fuel oil (BBM) was carried out by the Directorate General of Customs and Excise (DGCE) Ministry of Finance of the Republic Indonesia in the first semester of 2020 but the main focus of this study is only administrative issues and a simple simulation of the fuel excise tariff to calculate potential state revenue based on consumption levels fuel, fuel quality, and fuel price and the Multiplier Effect. In contrast to previous writings and studies, the purpose of this paper is to focus more on analyzing the possibility of applying carbon levies in Indonesia, both in the form of taxes, excise, and non-tax state revenues using existing laws. What commodities and activities should be subject to a carbon levy? What law will be used as the basis for the collection?

\section{LITERATURE REVIEW}

\section{1. Paris Agreement}

The Paris Agreement is an agreement in the United Nations Framework Convention on Climate Change (UNFCCC) on the mitigation of greenhouse gas emissions, adaptation, and finance. This agreement was negotiated by 195 representatives of countries at the 21st UN Climate Change Conference in Paris, France. After the negotiation process, this agreement was signed right on the commemoration of Earth Day on April 22, 2016, in New York, United States. As of March 2017, 194 countries have signed this agreement and 141 of them have ratified the agreement. Indonesia is one of the countries that signed this agreement on April 22, 2016. The global percentage of greenhouse gases ratified by Indonesia is $1.49 \%$. 
The purpose of establishing the Paris Agreement is contained in article 2, i.e.:

a. Holding the increase in the global average temperature to well below $2^{\circ} \mathrm{C}$ above preindustrial levels and pursuing efforts to limit the temperature increase to $1.5^{\circ} \mathrm{C}$ above pre-industrial levels, recognizing that this would significantly reduce the risks and impacts of climate change.

b. Increasing the ability to adapt to the adverse impacts of climate change and foster climate resilience and low greenhouse gas emissions development, in a manner that does not threaten food production.

c. Making finance flows consistent with a pathway towards low greenhouse gas emissions and climate-resilient development.

Based on various studies that have been carried out, including by the Organization for Economic Cooperation and Development (OECD), it is stated that using a market-based approach such as Carbon Pricing is one solution that can be applied to reduce greenhouse gas emissions (GHG). While Carbon Market Watch in its Policy Briefing (2017), stated that putting a price on carbon, based on the polluter pays principle, is a powerful policy to reduce greenhouse emissions in the fights against climate change.

What is carbon pricing? The World Bank (2020) defines carbon pricing is an instrument that captures the external costs of greenhouse gas (GHG) emissions - the costs of emissions that the public pays for, such as damage to crops, health care costs from heatwaves and droughts, and loss of property from flooding and sea- level rise and ties them to their sources through a price, usually in the form of a price on the carbon dioxide $\left(\mathrm{CO}_{2}\right)$ emitted. A price on carbon usually takes the form of either a carbon tax or a requirement to purchase a limited number of tradeable permits to pollute, commonly referred to as a cap and trade or emissions trading scheme.

A carbon tax, sometimes referred to as a fee, is a constant price for a given tonne of greenhouse gas, measured in $\mathrm{CO} 2$ equivalent or $\mathrm{CO} 2 \mathrm{e}$. The fee does not fluctuate based on the amount emitted but rather provides a constant and robust price signal to reduce pollution while a cap and trade system on the other hand fixes the total number of pollution permits allowed under the "cap" and allows the price to fluctuate according to the demand and hedging strategies of polluters. The demand for permits depends on the amount of pollution the industry emits and what options they can find to reduce their 
emissions. The initial supply is sold to emitters usually through an auction providing an initial price, a secondary market price emerges through buying and selling between emitters and other intermediaries (Carbon Market Watch, 2017).

\subsection{Excise}

Taxes that are selective for goods and services often referred to as excise, are the oldest form of taxation in the world. According to Sijbren Cnossen (2005) in his book Theory and Practice of Excise Taxation: Smoking, Drinking, Gambling, Polluting, and Driving, what distinguishes excise from other consumption taxes is the selectivity of coverage, discrimination in intent, and often some form of quantitative measurement in determining the tax liability. If other consumption taxes such as value- added tax (VAT) and retail sales tax (RSTs) are levied only to raise revenue, then excise is justified for other specific purposes. Besides that, excise collection is usually related to physical controls, while tax VAT or RSTs collection is usually through checks on book account and other evidence documents. Furthermore, Sijbren Cnossen also revealed some of the objectives of excise taxation, i.e.: to raise revenue for general purposes, to reflect external costs, to discourage consumption, to charge road users for Government-Provided services, and other purposes such as the imposition of levies on luxury goods.

According to Excise Law of The Republic Indonesia Number 11 of 1995 as amended by Law Number 39 of 2007, excise is the state levy imposed on certain good which has the following nature or characteristic :
a. its consumption needs to be controlled,
b. its circulation needs to be monitored,
c. its use can have a negative impact on society or the environment, or
d. its use requires the imposition of state levies for justice and balance.

High consumption of fossil fuels is believed to cause environmental damage due to carbon dioxide emissions that cause climate change as well as emissions of other materials that may accompany it, such as sulfur, carbon monoxide, lead, and nitrogen oxides. This causes many countries to impose excise on oil as a tax for negative externality. Taxes on fossil fuels that are theoretically included in excise in some countries are often called energy taxes or environmental taxes. 
As mentioned earlier, excise collection in Indonesia relies on physical inspection, so that a good can be designated as an excisable item if the goods are tangible and visible.

\subsection{Carbon Tax}

The first country to impose a carbon tax was Finland in 1990 as an instrument to mitigate climate change even though the country's contribution to global carbon dioxide emissions was only $0.3 \%$. This tax is collected based on the carbon content in fossil fuels with a tax rate of $€ 1.12$ per tonne of $\mathrm{CO} 2$-e when it was first started.

The reason for the imposition of a carbon tax on fossil fuels is to correct for negative externalities resulting from their use by increasing the price of energy consumption to reflect their social costs. This reason is similar to the reason for the imposition of excise tax on fossil fuels so that the imposition of carbon taxes can also be used as a substitute for excise or as a complement to existing excise taxes.

The scope of a carbon tax is broader than an excise, because this type of tax not only accommodates tangible and visible goods such as petroleum, coal, and LNG but can also be applied to activities that create a carbon footprint. For example, South Africa imposing excise on petroleum products, while for activities that emit carbon, such as cement factories, ceramic factories, and coal mining and handling activities, the country imposes carbon tax.

\subsection{Non-tax state revenues}

In 2018 the Indonesian government issued a new Law regulating non-tax state revenue with Law Number 9 of 2018. According to this law, Non-Tax State Revenues (PNBP) are levies paid by individuals or entities with benefits directly or indirectly for services or utilization of natural resources and rights obtained by the state, based on statutory regulations, which become the revenue of the Central Government outside of tax and grant revenues and are managed in the state revenue and expenditure budget mechanism.

The object of PNBP is all activities, things, and / or objects, which become a source of state revenue, other than taxation and grants which includes the use of natural resources; service; separated management of state assets; management of state property, fund management; and other state rights. This PNBP object has criteria: (i) 
implementation and government duties, (ii) the use of funds sourced from the state revenue and expenditure budget, (iii) management of state assets, and (iv) stipulation of statutory regulations.

\subsection{Assessment of carbon tax implementation plans}

An assessment of the implementation of the carbon tax on fossil fuel emissions has been carried out by the Office of Tax Analysis, The US Department of Treasury, as outlined in a Working Paper 115, January 2017. In principle, the imposition of taxes on fossil fuel emissions can use one of two approaches, namely the "upstream" or "midstream" approach. The two approaches differ at which point in the supply chain their tax collection is implemented. The upstream approach taxes the raw fuel, while the midstream approach taxes the fuel at a specified point in the supply chain before it reaches the final consumer. It is also possible to use a combination of these two approaches.

With the upstream system approach, the collection of the carbon tax (in the USA it is called excise) which will be charged to: crude oil upon arrival at the refinery, natural gas when it comes out of processing which is flowed through the piping system, or for gas passing through the processing system or pipeline, up to the end- user, and for coal when it leaves the mine. The imposition of excise is only for fossil fuels that are used domestically so that the exported goods will get an exemption from excise, as well as fuel for international flights. Carbon dioxide captured from fossil fuel plants or through industrial processes and stored permanently will be counted for tax returns. Fuels or fuel products that do not release emissions such as wax, lubricants, solvents, or chemical raw materials will also be exempted from excise duty.

In the midstream system approach, excise will be levied on fuel originating from petroleum when it leaves the refinery or when it is sold at the fuel station for use, natural gas when it leaves the local distribution center, and the fuel used by electric generating facilities or other industrial users whose excise was not previously imposed. It is also possible to use a combined upstream / midstream approach when collecting excise on upstream natural gas and coal and petroleum products.

Under either the upstream or the center approach, the tax will be based on calculated carbon dioxide emissions per unit of fuel. Table 1 shows the candidate calculated 
emissions and the tax per unit of fuel to be applied under the upstream and middle approaches assuming a tax of $\$ 49$ per metric tonne of carbon dioxide equivalent ( $\mathrm{mt}$ $\mathrm{CO} 2-\mathrm{e})$.

Table 1. $\mathrm{CO}_{2}$ content and tax rates for fossil fuels @ \$49/metric ton of carbon dioxide equivalent (mt CO2-e)

\begin{tabular}{|c|c|c|}
\hline Fuel & $\mathrm{CO}_{2}$ content $^{1}$ & Tax @ $\$ 49 / \mathrm{mt} \mathrm{CO} 2-\mathrm{e}$ \\
\hline \multicolumn{3}{|l|}{$\begin{array}{l}\text { Natural gas and coal } \\
(\text { Upstream or midstream } \\
\text { (approach })^{2}\end{array}$} \\
\hline Natural gas & $53.12 \mathrm{~kg} / \mathrm{mcf}$ & $\$ 2.60 / \mathrm{mcf}$ \\
\hline Anthracite & $2,578.68 \mathrm{~kg} / \mathrm{short}$ ton & $\$ 126.36 /$ short ton \\
\hline Bituminous & $2,236.80 \mathrm{~kg} / \mathrm{short}$ ton & $\$ 109.60 /$ short ton \\
\hline Sub-bituminous & $1,685.51 \mathrm{~kg} / \mathrm{short}$ ton & $\$ 82.59 /$ short ton \\
\hline Lignite & $1,266.25 \mathrm{~kg} / \mathrm{short}$ ton & $\$ 62.05 /$ short ton \\
\hline \multicolumn{3}{|l|}{ Petroleum } \\
\hline \multicolumn{3}{|l|}{$\begin{array}{l}\text { Midstream approach } \\
\text { (representative fuels): }\end{array}$} \\
\hline Gasoline & $8.89 \mathrm{~kg} / \mathrm{gallon}$ & \$0.44/gallon \\
\hline Diesel, home heating oil & $10.16 \mathrm{~kg} / \mathrm{gallon}$ & $\$ 0.50 /$ gallon \\
\hline Jet fuel & $9.57 \mathrm{~kg} /$ gallon & $\$ 0.47 /$ gallon \\
\hline \multicolumn{3}{|l|}{ Upstream approach: } \\
\hline Crude oil & $432 \mathrm{~kg} / \mathrm{bbl}^{3}$ & $\$ 21.17 /$ barrel \\
\hline \multicolumn{3}{|c|}{$\begin{array}{l}{ }^{1} \text { Source: http://www.eia.gov/environment/emissions/co2 vol mass.cfm. } \mathrm{CO}_{2} \\
\text { content parameters represent OTA's assessment of tax-relevant emissions and } \\
\text { should not be considered definitive for any carbon tax that may be enacted. } \\
{ }^{2} \text { For natural gas and coal, upstream and midstream approaches differ in the } \\
\text { point in the supply chain at which the fuel is taxed but not the form of the fuel } \\
\text { or the per-unit fuel tax at the point of taxation. } \\
{ }^{3} \text { Source: https://www.epa.gov/energy/ghg-equivalencies-calculator-calculations- } \\
\text { and-references }\end{array}$} \\
\hline
\end{tabular}

Source: Working Paper 115. Office of Tax Analysis. The US Department of the Treasury.

Under the upstream system, crude oil will be taxed based on its total carbon content regardless of the fuel and products used to produce it. This approach is needed to ensure that the tax is fully charged on fuel products which are later used for energy purposes. Fuels and fuel products whose emissions are significantly lower than the coefficient of Table 1 will be eligible to claim credits based on their lower emissions. This treatment may be somewhat challenging to tax non-fuel petroleum products that emit greenhouse gases as they break down over time. 
For power generation facilities and other stationary combustion sources, the midstream approach can instead tax actual emissions, as measured by a continuous emissions monitoring system, not fuel input. Measurable emission taxes are not currently possible for transportation fuels or natural gas used directly by residences or commercial establishments; for this use, some form of fuel-based tax will still be required. Under measurable emissions taxes, emissions from renewable fuels at power generation facilities and other point sources will initially be taxed at the same rate as emissions from fossil fuels but they can be made eligible to claim full or partial fuel-based credits. renewables used, depending on how the system wants to handle renewable fuel.

\subsection{Macroeconomic impacts on carbon tax}

Herbert Wibert Victor Hasudungan in his doctoral thesis entitled The Impact of Implementing Carbon Tax and Feed in Tariff: A CGE Analysis of the Indonesian Case has examined the macroeconomic impact of the imposition of carbon tax in Indonesia. This study uses a Computable General Equilibrium (CGE) model with a carbon tax rate of Rp. 100,000.00 per tonne of CO2 emissions generated by combustion of fossil fuels using three possible simulations of revenue recycling.

In the first simulation, it is assumed that there is a revenue neutralizing scheme where the income derived from carbon taxes is neutralized by reducing the income tax rate from labour. In other words, the income tax rate is allowed to be adjusted so that the government's net income can be balanced. The rates of taxes and other subsidies and government spending on goods and services are assumed to be fixed.

The CGE simulation results show that recycling carbon tax through the reduction of labour income tax has an increased impact on all GDP, both GDP factor cost and GDP market size. In addition, it can be seen that there is a decrease in the income tax rate of $3.24 \%$ which in turn leads to an increase in GDP. This implies that the increase in fuel prices due to the carbon tax was offset mainly by higher increases in household income due to reduced income tax rates. Thus, this causes the total domestic demand for goods and services to be higher due to an increase in expendable income which in turn will increase the aggregate national output. However, there was a deep contraction in the net export indicator of $5.11 \%$ due to a decline in exports of $0.14 \%$ and an increase in imports of $0.36 \%$. The contraction was influenced by expansion of the final combined domestic 
commodities, which resulted in higher demand for imported goods and services compared to exports. Indirect tax revenue increased quite strongly by $74.30 \%$. This implies that replacing carbon taxes with labour taxes leads to an expansion of national output so that the government gets more income from indirect taxes for national produced commodities. In addition, indirect tax is a component to estimate GDP market price in terms of expenditure. It was revealed that though the increase in net indirect tax increased sharply, but it did not really affect GDP on the market price in terms of expenditure because the ratio of net indirect tax to GDP market price from the expenditure side was less than $2 \%$.

In the second simulation, it is assumed that there is an adjustment in government spending on goods proportionately in response to the revenue generated from the carbon tax. Higher government spending in the simulation is expected to increase output in a balanced manner.

The CGE simulation results show that the application of a carbon tax with adjustments to government spending hardly affects GDP factor cost, however, GDP market size, both in terms of income and expenditure, has increased by $0.6 \%$ and $0.3 \%$. The application of a carbon tax on fuel will increase prices, which will encourage reallocation of production factors, especially in energy-intensive industries. In turn, changes in market factors have a significant effect on sectoral and income distribution. GDP factor cost only contracted very slightly by $0.006 \%$. This contraction is closely related to a slight decrease in the total salary component of $0.049 \%$, but on the other hand, the total capital bill slightly increased by $0.043 \%$. The application of a carbon tax with adjustments to government spending resulted in a decrease in government consumption spending by $0.07 \%$. This indicates that the negative effect of the carbon tax on the economy can be balanced with expenditure adjustments made by the government to shift aggregate demand which in the end this pattern causes an increase in GDP market price from the income side by $0.601 \%$ and from the expenditure side by $0.292 \%$. However, it should be noted that there will be a decrease in total exported goods by $0.304 \%$ and a decrease in imports by $0.469 \%$. Indirect tax net increased significantly by $45.991 \%$ which caused a slight increase in GDP market price from this perspective spending. The share of indirect tax does not have a significant effect on the increase in overall GDP. 
In the third simulation, it is assumed that government saving is an endogenous variable so that there is no revenue recycling to allow for a budget surplus. In other words, this third simulation is more representative of the bare-effect of the application of carbon taxes with the assumption of a very strong cateris paribus in it. This simulation aims to assess the impact of a carbon tax on the Indonesian economy when there is no compensation mechanism (revenue neutralizing).

The CGE simulation results on the application of a carbon tax without any compensation to the economy show a large increase in government net savings (budget surplus) of $43 \%$. Compared to the two previous simulations, all GDP macroeconomic indicators appear to be more detrimental because of the contraction in all GDP, both GDP factor cost and GDP market size. The decline in GDP in factor cost is related to a decrease in the components of both total capital claims $(-0.33 \%)$ and wages claims $(-0.29 \%)$. The GDP contraction on the market size from the expenditure side was slightly higher than the GDP factor cost contraction due to a significant decrease in indirect tax that the government could collect by $28.54 \%$. In other words, the equilibrium output tends to shift downwards which in turn will reduce the total net indirect tax revenue. From the trade side, both exports and imports showed a significant contraction of $-4.14 \%$ and $4.68 \%$. This is clearly due to an increase in energy prices because the imposition of carbon taxes is not implemented with any compensation to the economy so that the aggregate demand contraction is worse than simulations one and two.

\section{RESEARCH METHODS}

This research uses qualitative methods. According to the objectives of the research, this study is descriptive. Descriptive research is conducted to give more details of the phenomenon. The descriptive research aims to explain the mechanism of the process, present basic information, explain the hierarchy or series, and create a set of categories or patterns.

To achieve the research objectives, this research conducted several stages, i.e.:

a. The prevailing condition which aims to map the current conditions as a baseline. The data required is secondary data obtained from library research and data published by 
the Ministry of Environment and Forestry of The Republic of Indonesia or other institutions.

b. Identification objectives and needs which aim to identify the goals and objectives of the proposed regulation-making that are under existing environmental conditions, without having to violate existing laws.

c. Benchmarking, i.e. by collecting data related to carbon levy policies implemented in other countries as a reference, either using the name excise or tax.

d. Regulatory synchronization is an activity that aims to map and find out the extent to which existing laws and other regulations can be used as a basis for implementing carbon levies.

The results of this study are expected to be a consideration for the government to apply carbon tax in order to fulfill the mandate of Paris Agreement.

\section{ANALYSIS AND DISCUSSION}

\section{1. Indonesia's current condition}

According to data from the Ministry of Energy and Mineral Resources of The Republic Indonesia in 2015, energy consumption in Indonesia continues to increase in line with the increasing economic activity in all energy user sectors, including the industrial, transportation, household, commercial and other sectors. With an average annual increase of $3.2 \%$ (4.4\% without biomass), Indonesia's final energy consumption in 2013 reached 1,151 million BOE (barrel of energy). Fuel oil still dominates Indonesia's final energy consumption until 2013 with a share of $35 \%$ (46\%, without biomass), followed by biomass $25 \%$, coal $16 \%$, natural gas $15 \%$, electricity $10 \%$, and the rest is contributed by LPG, other fuel, and briquettes.

Total GHG emissions (sectoral plus generators) during the 2000-2013 period increased from 252 million tonnes of CO2e in 2000 to 476 million tonnes of CO2e in 2013 or increased by an average of $5.0 \%$ per year. In terms of energy demand (sectoral plus generators) for the same period, there was only an increase in energy demand by $3.7 \%$ per year. This indicates that an increase in energy by $1 \%$ will increase emissions by $1.4 \%$, which means that the composition of fossil energy used 
still dominates energy use in Indonesia. The conditions of GHG emissions from 2000 to 2013 can be seen in Table 2 .

Table 2. GHG Emissions from 2000 to 2013 in Indonesia (Million tonnes CO2-e)

\begin{tabular}{|c|c|c|c|c|c|c|}
\hline Year & Household & Industry & Transportation & Commercial & Others & Generator \\
\hline 2000 & 29.7 & 83.3 & 61.0 & 4.4 & 12.9 & 60.7 \\
\hline 2001 & 29.4 & 83.5 & 65.0 & 4.5 & 13.5 & 63.6 \\
\hline 2002 & 28.2 & 83.0 & 66.4 & 4.4 & 13.3 & 66.5 \\
\hline 2003 & 28.5 & 99.8 & 68.4 & 4.2 & 12.6 & 70.9 \\
\hline 2004 & 28.7 & 93.6 & 78.1 & 4.7 & 14.0 & 74.3 \\
\hline 2005 & 27.4 & 95.3 & 78.1 & 4.5 & 12.9 & 79.0 \\
\hline 2006 & 24.6 & 104.5 & 74.4 & 4.0 & 11.5 & 85.5 \\
\hline 2007 & 24.9 & 120.1 & 78.1 & 3.9 & 11.0 & 94.2 \\
\hline 2008 & 22.2 & 110.7 & 85.8 & 3.8 & 11.4 & 95.6 \\
\hline 2009 & 18.3 & 109.8 & 97.7 & 3.8 & 12.0 & 96.6 \\
\hline 2010 & 16.5 & 142.2 & 110.6 & 3.8 & 12.7 & 103.0 \\
\hline 2011 & 16.3 & 143.3 & 119.4 & 3.4 & 11.0 & 117.8 \\
\hline 2012 & 16.9 & 152.5 & 133.2 & 3.5 & 11.5 & 132.8 \\
\hline 2013 & 18.2 & 162.0 & 138.5 & 3.2 & 10.4 & 143.2 \\
\hline
\end{tabular}

Source: The Energy Sector GHG Emission Inventory Data, the Center for Data and Information Technology for Energy and Mineral Resources, Ministry of Energy and

Mineral Resources of The Republic of Indonesia (2015).

Recommendations for the imposition of a carbon tax to mitigate carbon emission in Indonesia have been written in several published articles, including those from Martha Maulida (2014) and I Dewa Made Raditya Margenta (2020). They recommended imposing a carbon tax on fossil fuels, motorized vehicles that use fossil fuels, power generation, and energy-incentives such as cement, petrochemical, and metal. It is hoped that the imposition of a carbon tax will help Indonesia to meet the targets set in the Nationally Determined Constributions (NDC).

In principle, the suggestions from the authors above are in line with Indonesia's commitments which have compiled a Nationally Determined Contribution or what is called (NDC) signed in Paris in 2015 which states that Indonesia will be able to reduce carbon emissions by 2030 by $29 \%$ if do business as usual. However, Indonesia will be able to reduce $\mathrm{CO} 2$ by $41 \%$ if it gets support and cooperates internationally. 
Published articles, which contain recommendations on the imposition of a carbon tax in Indonesia, generally do not discuss the legal basis for this taxation. Is it necessary to make a separate law? Is it sufficient to use existing laws? If we read article 23 A of the 1945 Constitution of The Republic Indonesia in 2015 which states that "taxes and other levies that are compelling for the needs of the state are regulated by law", then to impose a tax on carbon must also be based on the law.

The discussion of carbon taxes in various countries cannot be separated from taxes on fossil fuels, because the use of these commodities for energy contributes the largest to the ongoing greenhouse effect, which ultimately leads to climate change. In the case of Indonesia, fossil fuels such as petroleum, natural gas, and coal, of course, are already subject to consumption tax in general such as Value Added Tax (VAT), Local Tax (for fuel), or Non-Tax State Revenue (coal), but the type of tax or the levy is not meant to overcome negative externalities. The imposition of consumption tax in the form of VAT or Good and Service Tax (GST) on these goods is also commonly done in various countries, and even though it is then subject to negative externality taxes such as energy tax, excise tax, environmental tax or carbon tax, it does not mean there is double taxation on the object, the reasons for the imposition of these two types of consumption tax are different.

\section{2. Bench markings of tax collection on carbon dioxide emissions}

The taxation of fossil fuels using the name of an environmental tax, energy tax, or excise predates the issue of carbon taxes. Philosophically, the basic imposition of carbon taxes is the same as environmental / energy / excise taxes because, in principle, carbon taxes are levies imposed on goods or activities that cause negative externalities or often called Pigouvian tax. Types of levies on carbon emissions in selected countries can be seen in Table 3. 
Table 3. Types of carbon levies in selected several countries

\begin{tabular}{|c|c|c|c|c|}
\hline No. & Country & $\begin{array}{c}\text { Excise/Energy/ } \\
\text { Environmental Tax }\end{array}$ & $\begin{array}{l}\text { Carbon } \\
\text { Tax }\end{array}$ & Explanation \\
\hline 1. & Sweden & Yes (energy tax) & Yes & $\begin{array}{l}\text { All fossil fuels based on } \\
\text { carbon content. } \\
\text { Example : fuel oil } \\
\text { SEK/m3 }\end{array}$ \\
\hline 2. & Finland & $\begin{array}{l}\text { Yes (energy content } \\
\text { tax on fossil fuel and } \\
\text { in electricity } \\
\text { consumption) }\end{array}$ & Yes & $\begin{array}{l}\text { Coal is exempted from both } \\
\text { taxes. } \\
\text { Participate in the EU } \\
\text { Emission Trading System } \\
\text { (ETS) }\end{array}$ \\
\hline 3. & Netherland & $\begin{array}{l}\text { Yes (excise on petrol, } \\
\text { diesel, and LPG) }\end{array}$ & $\begin{array}{l}\text { Don't have } \\
\text { an explicit } \\
\text { carbon tax }\end{array}$ & $\begin{array}{l}\text { Participate in the EU } \\
\text { Emission Trading System } \\
\text { (ETS) }\end{array}$ \\
\hline 4. & Japan & No & Yes & $\begin{array}{l}\text { Carbon Tax for Crude Oil } \\
\text { and Oil Products, Gaseous } \\
\text { Hydrocarbon, coal }\end{array}$ \\
\hline 5. & Thailand & $\begin{array}{lr}\text { Yes (excise } & \text { on } \\
\text { petroleum } & \text { and } \\
\text { petroleum } & \\
\text { products,etc }) & \end{array}$ & N/A & \\
\hline 6. & Singapore & $\begin{array}{l}\text { Yes } \quad \text { (excise } \\
\text { petroleum and } \\
\text { biodiesel blends) }\end{array}$ & Yes & $\begin{array}{l}\text { The carbon tax is applied to } \\
\text { the total direct emissions of } \\
\text { facilities that emit } 25,000 \\
\text { tCO2e or more of emissions } \\
\text { annually. }\end{array}$ \\
\hline 7. & Philippines & $\begin{array}{l}\text { Yes (excise on } \\
\text { petroleum products } \\
\text { and mineral products } \\
\text { such as coal) }\end{array}$ & N/A & \\
\hline 8. & USA & $\begin{array}{l}\text { Yes (excise on } \\
\text { petroleum products : } \\
\text { Federal and several } \\
\text { States) }\end{array}$ & Yes & $\begin{array}{l}\text { Carbon tax on fossil fuels = } \\
\text { excise tax } \\
\text { Carbon tax in several States }\end{array}$ \\
\hline 9. & $\begin{array}{l}\text { South } \\
\text { Africa }\end{array}$ & $\begin{array}{l}\text { Yes (excise on } \\
\text { petroleum products) }\end{array}$ & Yes & $\begin{array}{l}\text { Carbon tax on activities: } \\
\text { Industrial Process, Fuel } \\
\text { Combustion, Fugitives }\end{array}$ \\
\hline
\end{tabular}

Source: Compiled by author form various sources. 
From some of the countries above, the authors elaborate on carbon levies in South Africa because it is interesting to analyze. After all, this country differentiates between excise and carbon tax. Before implementing the carbon tax, South Africa had imposed several levies on petroleum products which consisted of Petrol, Diesel, Bio-Diesel, Unmarked Aliphatic Hydrocarbon Solvents, and Unmarked Illuminating Kerosene (Unmarked Paraffin). These products are subject to the payment of Excise Duty, Fuel Levy, and Road Accident Fund (RAF) Levy if consumed within the RSA (Republic of South Africa) and Excise Duty only if consumed in any of the other SACU (The Southern African Customs Union) Member States.

South Africa began imposing Carbon Tax (CBT) on June 1, 2019, and this CBT was imposed on entities in the country that operate emissions generation facilities at a combined installed capacity equal to or above the carbon tax threshold. In the initial phase, the carbon tax rate was 40 South African Rand (R) per tonne of carbon dioxide equivalent emission. This rate will increase annually by inflation plus 2 percent until 2022, and annually by inflation thereafter.

Calculation of carbon emissions for Industrial Process, Fuel Combustion (Stationary and Non-Stationary), and Fugitive (Oil \& Natural Gas and Coal Mining \& Handling) using a certain formula regulated by law. For example, the calculation of carbon emissions for industrial processes uses the following formula:

- Emissions Factors: $(\mathrm{C} \times 1)+(\mathrm{M} \times 23)+(\mathrm{N} \times 296)+(\mathrm{H} \times 11.900)+(\mathrm{T} \times 5.700)+(\mathrm{S} \times$ 22.200) $=\mathrm{X}$, where $\mathrm{X}=$ emission factor in $\mathrm{CO} 2$ equivalent per tonne $(\mathrm{H}), \mathrm{C}=\mathrm{TONNE} \mathrm{CO} 2 /$ tonne product, $\mathrm{M}=\mathrm{TONNE} \mathrm{CH} 4$ / tonne product, $\mathrm{N}=\mathrm{TONNE} \mathrm{N2O} /$ tonne product, $\mathrm{H}=\mathrm{TONNE}$ $\mathrm{C} 2 \mathrm{~F} 6$ / tonne product, $\mathrm{T}=\mathrm{TONNE} \mathrm{CF} 4 /$ tonne product, $\mathrm{S}=\mathrm{TONNE} \mathrm{SF} 6 /$ tonne product Emissions Equivalent: $(\mathrm{G} \times \mathrm{H})=\mathrm{P}$

From the formula above, we can see that South Africa has also taken into account the emission of other gases that can cause the greenhouse effect, the calculation of the number of gas emissions other than carbon dioxide is then equated with carbon dioxide emissions using certain calculations agreed by experts.

\section{3. Implementation of carbon levies in Indonesia.}

We use the term of carbon levy, with the aim of not confusing with the term of tax. If it is forced to keep using the term carbon tax, it is feared that it will be more difficult 
to implement, due to the current taxation law, which is administered by the Directorate General of Taxes Ministry of Finance of the Republic Indonesia, does not regulate negative externality taxes such as carbon tax. By using the terminology of carbon levies, this is a neutral term so that if in the future Indonesia will impose levies on carbon, it is hoped that it will be able to use existing laws such as the Excise Law and Non-Tax State Revenue Law as well.

To implement accountable carbon levies, there are several things that can be used as a foundation, including:

a. Carbon levies should encourage the development of new and renewable energy.

b. The design of the carbon levy must be fair and transparent. Levies are only imposed on goods that will produce carbon dioxide emissions if used or for activities that leave a carbon footprint (except for activities that create a carbon footprint but administration of the collection is difficult to implement, such as activities on a household scale).

c. Carbon levies are not imposed on fuels, although their use as energy results in carbon dioxide emissions, these fuels are included in the category of renewable fuels (for example, palm oil-based biofuels).

Tangible and visible goods such as petroleum and its products, natural gas, or coal can be subject to carbon levies under the name of excise, and its administration is not difficult to enforce.

The addition of excisable goods has been accommodated in Article 4 paragraph (2) of Excise Law of The Republic Indonesia Number 39 of 2007 which states that the addition and reduction of types of excisable goods are further regulated by a Government Regulation. Although according to the explanation of this paragraph, it still requires the approval of the House of Representatives. But, in principle, there is no need to make a new Law. We propose for these activities to temporarily use the Non-Tax State Revenue Law before we have a more appropriate law to handle it. Is this the right thing? There is still a need for in-depth discussion to address this issue.

Industrial activities in South Africa are subject to a carbon tax, and it is also possible that the industry uses fuels which are the object of excise, so how is the carbon tax 
calculated? This is not a problem, because the Customs and Excise Department is the institution responsible for carrying out the administration of collecting carbon and excise taxes. Of course, there are mechanisms and regulations for this.

By using references from policy papers from the US Department of Treasury and best practices from South Africa, Indonesia can imitate the two countries in implementing carbon levies. Figure 2 shows a brief overview of possible carbon levies implementation in Indonesia. The legal basis for the imposition of carbon levies can use the Excise Law and the Non-Tax Revenue Law as well.

The object of excise is tangible and visible goods so that it can be used for fossil fuel commodities which include natural gas (LNG), petroleum products, and coal, while the object of carbon levies in the form of activity can use the legal basis of the Non-Tax Revenue Law. The principle of the proposed carbon levy already takes into account the possibility of multiple levies on the same object, so it is proposed that fossil fuels be used for industrial processes or will be used for power generation, obtaining excise-exemption facilities. If the excise has already been paid, then the value of the excise will be calculated when the industry will pay off its carbon levies.

Payment of carbon levies by industrial processes or similar activities can be made periodically using a self-assessment system. It is also necessary to establish an institution whose task is to audit carbon emissions from an activity that leaves a carbon footprint. The function of this audit is primarily to monitor the compliance of entrepreneurs or institutions that are subject to carbon levies. This institution can be under the Ministry which has the competence to carry out mass and energy balance audits of industrial processes or similar activities. To clarify our proposed carbon levy scheme, let's see Figure 2. 
Figure 2. Carbon Levy Scheme (Proposal)

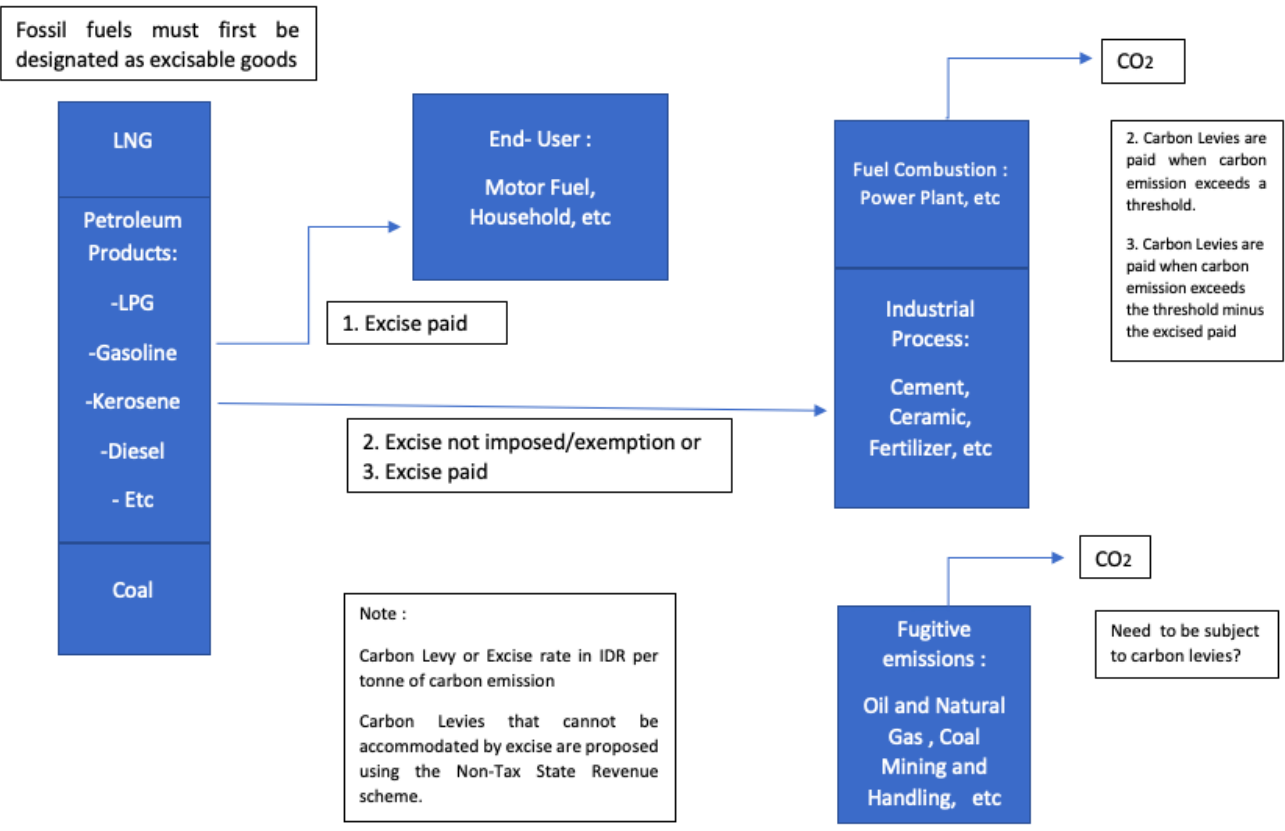

Source: Author

In principle, carbon levies can be carried out with an excise scheme, especially for tangible objects such as fossil fuels (natural gas, petroleum, and coal). The amount of excise that must be paid is based on the amount of carbon dioxide emissions if the fuel is used as energy. For example, if the excise rate is set at IDR 100,000 for every ton of carbon dioxide emissions, then we can have the excise rate per liter for gasoline and diesel oil as follows:

One liter of gasoline when burned will emit $2.348 \mathrm{~kg}$ of carbon dioxide emissions, while one liter of diesel oil will emit $2.684 \mathrm{~kg}$ (conversion for calculations using Table 1.). From this data, we can determine the excise rate for gasoline is IDR 195.55 / liter and IDR 223.49 for diesel oil / liter.

The imposition of carbon levies for industrial processes and such activities cannot use the excise mechanism and is proposed to use a non-tax state levy mechanism. The mass of carbon emissions from such activities can be measured by installing an instrument at the site where carbon dioxide is released into the air. Payment of carbon levies is made periodically based on the accumulated carbon dioxide emitted (eg. once a month) using a self-assessment system. 
From the scheme in Figure 2, we propose that the administration of carbon levies can be assigned to two institutions under the Ministry of Finance of the Republic Indonesia, excise is administered by the Directorate General of Customs Excise (DGCE) while PNBP is by the Directorate General of Budget (DGB). There is also a need for regulations that bridge administration in the two institutions, for example, regulations regarding restitution on carbon levies. It is possible to refund carbon levies that have been paid, for example, a factory whose carbon emissions have not exceeded the threshold, while in the production process the factory uses fossil fuels that have already paid excise as energy.

Does a carbon levy also need to be implemented for fugitive emissions? According to Wikipedia, fugitive emissions are emissions of gases or vapors from pressurized equipment due to leaks and other unintended or irregular releases of gases, mostly from industrial activities. As well as the economic cost of lost commodities, fugitive emissions contribute to air pollution. Based on data from the Ministry of Environment and Forestry compiled by I Dewa Made Raditya Magenta as shown in Figure 3, it can be seen that fugitive emission is still relatively small compared to fuel combustion emission. On this basis, carbon levies for fugitive emission can be postponed for a while.

Figure 3. Comparison between fuel combustion and fugitives as the carbon emitter

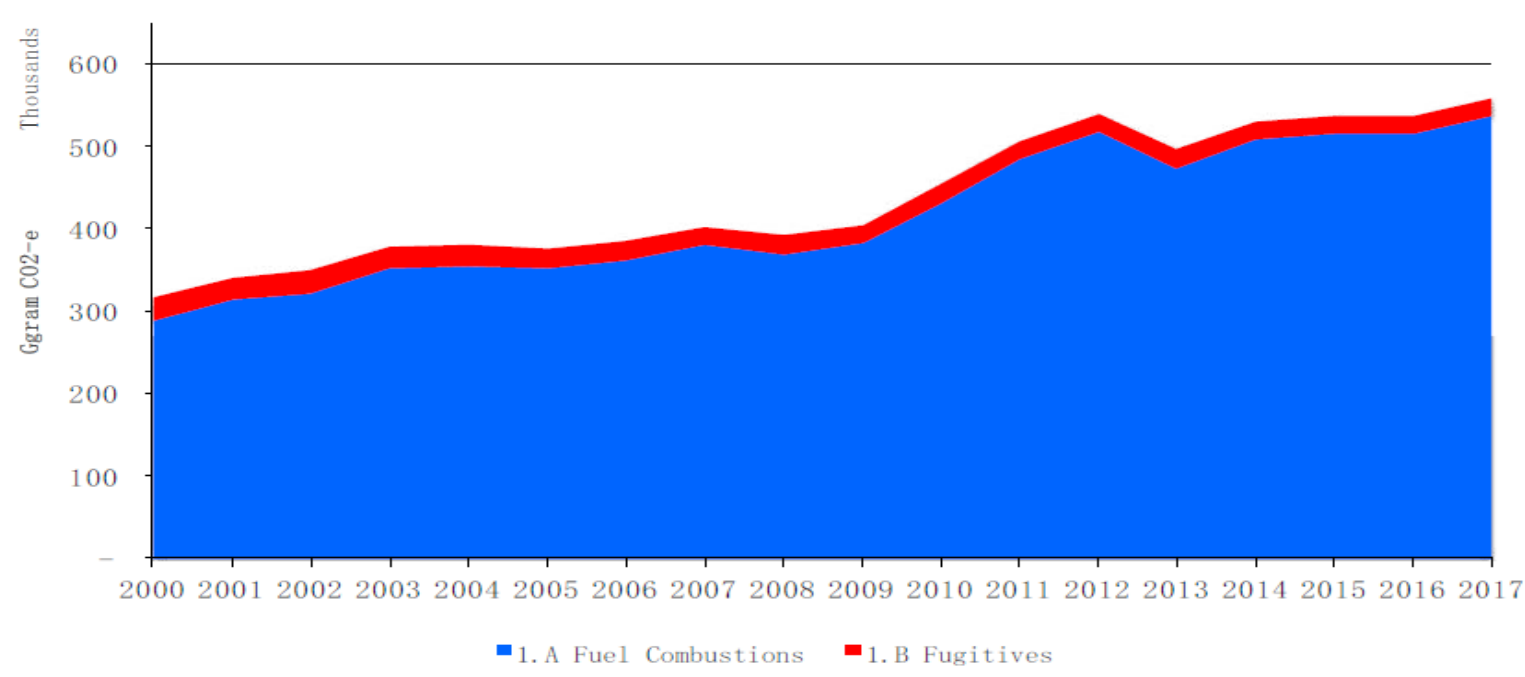

Source: Ministry of Environment and Forestry (2019). 


\section{CONCLUSION}

As one of the countries that has ratified the Paris Agreement, Indonesia inevitably has to fulfill its commitment to Paris in 2015 which states that Indonesia will be able to reduce carbon emissions by 2030 by $29 \%$ if do business as usual or will be able to reduce CO2 by $41 \%$ if it gets support and cooperates internationally, and carbon taxes are a powerful tool for reducing carbon dioxide emissions. Ideally, every activity that creates a carbon footprint is subject to a carbon tax, but this is not an easy matter so that only certain activities with a significant scale of emissions can be covered under carbon tax regulations.

Using the current law, Indonesia can carry out taxation of carbon emissions, but in order not to confuse the term of tax, whose administration is under the responsibility of the Directorate General of Taxes, we recommend using the term carbon levy. Carbon levies on fossil fuels can be imposed with an excise tax scheme, while activities that create a carbon footprint such as in power plants or industrial processes can use a nontax state revenue (PNBP) scheme. What needs to be prepared is to make regulations that bridge the two institutions that administer and enforce the law on these two types of carbon levies (in this case the Directorate General of Customs and Excise and the Directorate General of Budget).

To be able to calculate the amount of carbon emission in industrial activities and such activities, it is necessary to appoint or establish an institution that is obliged to carry out compliance audits of legal entities that are subject to carbon levies. This institution is indispensable because the carbon levy payment system inevitably has to be carried out periodically through a self-assessment system.

\section{LIMITATION AND SUGGESTIONS}

This paper only discusses carbon tax, which is a type of carbon pricing as a means of mitigating climate change. Other types of carbon pricing according to the United Nations are Emission Trading System (ETS) and Emission Reduction Funds. There are several publications that have discussed the advantages and disadvantages of these three types of carbon pricing. 
This paper also does not discuss earmarking which is a characteristic of Pigouvian tax, which is not found in other types of consumption tax such as value-added tax (VAT), good and service tax (GST), or sales tax. Both carbon and excise taxes principally are Pigouvian taxes, so when discussing these two types of taxes, the issue of earmarking should also be discussed. Earmarking means the return of part of the funds obtained from taxes to mitigate externalities caused by the consumption of a good or the occurrence of an activity. The earmarking funds from this carbon levy can be used for research and development of environmentally friendly energy, or to subsidize the price of renewable fuels.

If Indonesia is serious about implementing a carbon tax, the Ministry of Finance together with several other relevant ministries should immediately prepare a comprehensive policy paper on the impact of carbon levies on the Indonesian economy and its roadmap.

\section{REFERENCES}

Air Quality in Indonesia (2020). Retrieved from https://www.iqair.com/indonesia on September 16, 2020 on September 16, 2020.

Carbon Market Watch (2017, September). Policy Briefing : Pricing Carbon to Achieve Paris Goal. Retrieve from https://carbonmarketwatch.org/wpcontent/uploads/2017/09/CMW-PRICING-CARBON-TO-ACHIEVE-THE-

PARIS-GOALS_Web_spread_FINAL.pdf on September 2, 2020.

Cnossen, Sijbern (2005). Theory and Practice of Excise Taxation: Smoking, Drinking, Gambling, Polluting, and Driving. Oxford University Pres.

Customs and Excise. Excise Duty and Levies. Government of South Africa. Retrieved from https://www.sars.gov.za/ClientSegments/CustomsExcise/Excise/Pages/default.aspx on July 30, 2020.

Data Inventory Emisi GRK Sektor Energi. (2015). Pusat Data dan Teknologi Informasi Energi dan Sumber Daya Mineral, Kementerian Energi dan Sumber Daya Mineral.

Hasudungan, Herbert Wibert Victor. (2016). The Impact of Implementing Carbon Tax and Feed-in Tariff : A CGE Analysis of the Indonesian Case. Doctoral Thesis. University of Dundee. Retrieved from https://discovery.dundee.ac.uk/en/studentTheses/the-impact-of-implementingcarbon-tax-and-feed-in-tariff on September 5, 2020.

Horowitz, J., Cronin, JA., Hawkins, H. , Konda, L., \& Yuskagave, A. (2017). Methodology for Analyzing a Carbon Tax. Working Paper 115. Office of Tax Analysis. The US Department of the Treasury.

Margenta, I Dewa Made Raditya (2020, June 15). Carbon Tax Implementation in Indonesia. The Purnomo Yusgiantoro Center. Retrieved from https://www.purnomoyusgiantorocenter.org/carbon-tax-implementation-inindonesia/ on August, 16,2020. 
Maulidia, Martha. (2014,April 29). Carbon tax for Indonesia : Time to act now. The Jakarta Post. Retrieved from https://thejakartapost.com/news/2014/04/29/carbontax-indonesia-time-act-now.html on July 12, 2020.

Newburger, Emma. (2019, October 10). A carbon tax is single most powerful way to combat climate change, IMF says. Retrieved from https://www.cnbc.com/2019/10/10/carbon-tax-most-powerful-way-to-combatclimate-change-imf.html on September 12,2020

OECD (2019). Taxing Energy Use 2019 : Country Note - Finland. Retrieve from https://www.oecd.org/tax/tax-policy/taxing-energy-use-finland.pdf on September 3, 2020.

Paris Agreement (2015). United Nations.

Riyanto,Bambang, dan Adji,Arti. (2019). Naskah Akademis Undang-Undang Cukai. Penelitian dan Pelatihan Ekonomika dan Bisnis, Fakultas Ekonomika dan Bisnis UGM.

Sweden Energy and Carbon Tax Policy: Rethinking Decarbonization Incentives- Policy Case Study.

Undang-Undang Republik Indonesia Nomor 11 Tahun 1995 Tentang Cukai Sebagaimana Diubah Dengan Undang-Undang Republik Indonesia Nomor 39 Tahun 2007.

Undang-Undang Republik Indonesia Nomor 16 Tahun 2016 Tentang Pengesahan Paris Agreement to the United Nations Framework Convention on Climate Change (Persetujuan Paris Atas Konvensi Kerangka Kerja Perserikatan Bangsa-bangsa Mengenai Perubahan Iklim).

Undang-Undang Republik Indonesia Nomor 9 Tahun 2018 Tentang Penerimaan Negara Bukan Pajak.

Kajian Ekstensifikasi Cukai Bahan Bakar Minyak. (2020), Direktorat Teknik dan Fasilitas Cukai, Direktorat Jenderal Bea dan Cukai.

United Nations. Climate Change. About Carbon Pricing. Retrieve from https://unfccc.int/about-us/regional-collaboration-centres/the-ci-acainitiative/about-carbon-pricing\#eq-4 on September 3, 2020

World Bank Group. (2020). State and Trends of Carbon Pricing.

Wikipedia. Fugitive emission. Retrieved from https://en.wikipedia.org/wiki/ Fugitive_emission on September 12, 2020. 